\title{
An Economic "Commons" Tragedy for Research Libraries: Scholarly Journal Publishing and Pricing Trends
}

\author{
Gary D. Byrd
}

The recent dramatic increases in both the numbers and prices of scholarly journals are evidence of a distorted economic marketplace for scholarly information. They can also be viewed as evidence of an impending economic "commons" tragedy for this nation's research libraries. The general economic principles underlying this tragedy were popularized in a nontechnical and very influential 1968 essay by Garrett Hardin called "The Tragedy of the Commons." The strategies needed to manage our research library commons effectively will require a fundamental reshaping of the present system of scholarly communication. The leadership for making the necessary changes must come from the research library community.

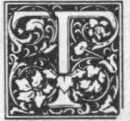

he venerable, centuries-old system of scholarly publishing and collection building in research libraries is in very real danger of collapse. Dramatic increases in both the numbers and prices of scholarly journals, especially scientific scholarly journals, are the most obvious manifestation of this impending crisis. For the past two decades journal prices in the United States have outpaced general inflation by rates that would be totally unacceptable in other sectors of our economy. In 1989, for example, journal prices increased by more than two times the Consumer Price Index (CPI) and, as recently as 1987 , the rate of price inflation was more than five times the CPI. ${ }^{1}$ Not only do prices increase dramatically, but the number of new journals also continues to "proliferate," as Herb White puts it, "in total disregard of all economic indicators." "One publisher," he notes, "reported that over a period of time he had started 180 new journals and canceled five. ${ }^{\prime 2}$

To date, none of the attempts by research libraries to cope with these dual crises of information glut and spiraling price inflation have been very successful. In fact, the most common strategies, that is, pleading for a larger acquisitions budget, or transferring dollars from monographs to the serials budget, have actually aggravated the problem by accommodating or hiding it rather than dealing with underlying causes. Even worse, argues White, these tactics destroy "any remaining vestige of a suggestion that library materials allocations as between monographs and serials [follow] any sort of professionally developed library plan. ${ }^{\prime \prime 3}$ Clearly, current distortions in the scholarly information marketplace threaten the ability of research libraries to continue to carry out their mission of collecting, preserving, and providing access to the scholarly rec-

Gary D. Byrd is Assistant Director for Finance, Planning, and Research at the Health Sciences Library, University of North Carolina, Chapel Hill, NC 27599.

๑1990 Gary D. Byrd. 
ord. Since research libraries are central to our current system of scholarly communication, a threat to their basic mission must be considered a threat to scholarly communication in general.

A puzzling and troubling aspect of this problem for research librarians has been the fact that until very recently (and to a large extent, even today) the scholars and publishers, who create, market, and ultimately consume journals and other records of scholarship, have seemed to ignore or to be unaware of the problems this explosion in scholarly journal numbers and prices is causing for libraries. Herb White suggests that this is because research libraries find themselves in a sort of never-never land between the "true vendor/client relationship" of scholarly publishers and the scholars who write for and then read their publications. Thus, "publishers don't treat us as customers, they treat us as purchasing agents, who simply perform the routine tasks we are told to perform." And because scholars, who do not directly experience the price increases, show "no objection to any of [the publishers' pricing] tactics . ... , [they] are furious not with the journal publishers but with us [when we] . . . hesitantly, apologetically ... apprise them of this problem."

The economic relationship among the producers, consumers, and distributors of scholarly publications is central to understanding both the causes of, and the potential solutions to, this impending breakdown in our system of scholarly communication through research libraries. The sections that follow review key papers and monographs dealing with the microeconomic principles that underlie the relationship among scholars, publishers, and research libraries.

The theories of supply and demand and the way these affect the exchange of goods and services among the three direct participants in the scholarly communication system are important for an understanding of the individual components of the system. But I will argue that they must be seen as part of a much more basic and fundamental economic principle. This principle, usually called the "Tragedy of the

\begin{abstract}
"Hardin describes how shared public resources (the 'commons') may eventually be destroyed when individuals are allowed unrestrained freedom to exploit them for personal gain."
\end{abstract}

Commons," was vividly described by Garrett Hardin in his 1968 essay by that title in Science. ${ }^{5}$ The essay deals primarily with the way cultural norms of individual independence and freedom of action endanger our common environmental resources. However, the "tragedy" Hardin describes has much wider economic implications for the way societies manage all shared public resources, including the resources in our research libraries. Briefly, Hardin describes how shared public resources (the "commons") may eventually be destroyed when individuals are allowed unrestrained freedom to exploit them for personal gain.

The current distortions in the scholarly information marketplace are evidence of a commons tragedy centering around our nation's research libraries, which share many of the characteristics of Hardin's commons. But, before describing this tragedy in more detail, we need to review the characteristics of scholarly information resources and the microeconomic relationships among publishers, research libraries, and scholars.

\section{THE NATURE OF SCHOLARLY INFORMATION}

One essential key to understanding these economic relationships is the resource that is produced and consumed, that is, scholarly information. When regarded as a commodity, scholarly information, or just "information" or "knowledge" (synonyms used by many who write about these issues) has many qualities that distinguish it from tangible products, like automobiles or wheat, on which classic economic theories are based. Harlan Cleveland posits the following list of unusual economic characteristics of in- 
formation: it is expandable, compressible, substitutable, transportable, diffusive, and sharable. ${ }^{6}$ The last of these characteristics, he says, the propensity for this sharing resource to leak, is "eroding the doctrine that knowledge can be owned, exchanged, and monopolized the way 'real' resources can." ${ }^{\prime 7}$ Pat Molholt expands on Cleveland's list with the following additional characteristics of information.

We are dealing with:

- a commodity that does not depreciate, with all this implies for financing, tax structures, and accounting principles;

- a resource that is freely available unless artificially impounded; whereas economic theories focus on scarcity;

- an intangible that can render people jobless and force whole organizations to restructure in order to survive;

- a resource that thrives on reuse, repackaging, recycling; one that has been growing exponentially and under completely unconventional rules;

- a resource that has, as an important aspect of its use, something uncontrollable and unpredictable-serendipity.

Robert Taylor describes four other important characteristics of scholarly information that can help us understand the ways publishers, scholars, and research libraries produce and exchange this unique economic good: (1) "A person cannot know before seeing (hearing) ... information, whether or not it is of use." (2) Knowledge "about a chunk of information ... in some ways decreases the need for that chunk because one may already possess a part of the information." (3) "Many people can know the same facts, or own the same chunk of information without depriving others." And (4) "we tend to overproduce and to overconsume information. ${ }^{\prime \prime 9}$

Together, these characteristics of scholarly information show it to be a poor example of the pure private goods that economists use to model the interaction of buyers and sellers in a competitive market. In a perfectly competitive market, many rival firms produce and sell standardized goods or services at quantities and prices determined by the total supply of, and total demand for, those goods or services. Perfect information about the quantity and quality of those goods and services is available to all producers and consumers. Finally, and most importantly for an understanding of the scholarly information "marketplace," the sale and purchase of goods and services in a competitive market causes no costs or benefits to third parties not participating directly in the sale or purchase transactions. (In economic jargon, there are no "externalities" to these transactions.)

On the other hand, scholarly information does share many, but not all, of the characteristics of public or social goods. Social goods are often, but not always, produced and provided to consumers by government or other public agencies, or by employees of these agencies. More importantly, they are goods that cannot easily be excluded from individuals who fail to pay for the service or benefit received. This "free rider" effect brings to mind Cleveland's observation that information has a propensity to "leak." Pure public goods can provide benefits simultaneously to more than one individual (often whole populations) without any additional cost. (Again, in technical economic jargon, the production of the good for the benefit of any one person results in positive externalities for all persons in a society and zero marginal costs for those extra benefits.)

Fritz Machlup argues that knowledge is, in fact, a public or social good " of the purest type. ... There may be a cost of the transfer of knowledge, of teaching it and learning it, but there is no additional cost of using it once it has been acquired. ${ }^{\prime \prime 10}$ Lawrence White notes that because the marginal cost to disseminate information "is frequently very low or zero, .... we ought to be encouraging ... . [its] maximum distribution ... once it is in existence." But, maximum free public distribution "may well interfere with the long run considerations of producing a flow of new information... [since] people are not going to invest resources in producing information unless they think they are going to get a net gain from it." 11 This economic conflict between the private, marketplace incentives for the production of 
new information and the public, social incentives to subsidize wide dissemination of existing information is one of the keys to the tragedy of the commons explored below. While basically a public or social good that is widely available at little or no cost, scholarly information also has characteristics that make its production and some forms of distribution, like journals, financially attractive to market for commercial profit. This leads directly to the question of economic value.

\section{THE VALUE OF SCHOLARLY INFORMATION}

Defining an accurate economic value for scholarly information is complicated by uncertainty. In contrast to most commodities, like coffee, for which "people usually have a pretty good idea of how much [more] ... would contribute to their happiness," notes Machlup, "we cannot know what a piece of knowledge may be worth to us before we know what it is." (Remember Taylor's observation that it is impossible to know about information before seeing or hearing it, and that, ironically, knowledge about a chunk of information decreases our need for it.)

\section{"Because scholars can never be sure what piece of information may prove useful . ...they have a strong incen- tive to encourage publishers to pub- lish everything which might be use- ful and to encourage research libraries to buy everything pub- lished."}

In his 1970 dissertation on the scientific journal market, Sanford Berg noted that scholars "cannot be completely certain about which items in [a] . . . stock of scientific information will be needed." Thus, "the result is a tendency to be complete rather than selective when organizing a reference library. "13 Because scholars can never be sure what piece of information may prove useful (and because serendipity often leads to unexpectedly useful in- formation), they have a strong incentive to encourage publishers to publish everything which might be useful and to encourage research libraries to buy everything published.

Another more technical aspect of this uncertainty characteristic of scholarly information has been described more recently by Machlup ${ }^{14}$ and Aatto Repo. ${ }^{15}$ They argue that the failure to distinguish between the "use value" (or "value-inuse") and the "exchange value" of scholarly information leads to inaccurate estimates of value. Use value includes the qualitative measures of how successfully individuals use the content of particular information products to accomplish information tasks. Exchange value includes economic measures of the marketplace where individuals and organizations produce, store, and exchange information products and services. Exchange values can be measured using fairly objective empirical data, while use value can only be measured subjectively by individuals, based on what they expect or perceive. The problem in much of the literature on the economics of information, says Repo, is that researchers "skip from exchange values to value-in-use . . . without realizing the implications of the change."16

Ironically, Sanford Berg's study, which accurately describes this uncertainty characteristic of scientific information, ${ }^{17}$ has been strongly criticized by Machlup for failing to make the distinction between use value and exchange value. Machlup argues that Berg and others are "overzealous" in their attempts to overcome the uncertain value of information by trying to quantify or objectively measure the total benefits or value to society of scholarly information. They do this by substituting projected individual estimated benefits (use value) for actual measures of the information marketplace (exchange value). "Most economists have long since abandoned as hopeless and irrelevant the aim of measuring the total utility or total benefits ... of a class of good or service," says Machlup, because "demand. . . for any one good or service is [based on]. . . the assumption that the prices of all other goods and services are given and un- 
changed, and hence the benefits which buyers of a particular good obtain. . . would depend on millions of other prices. ${ }^{\prime 18}$

This argument, though rather technical and complex, is also another key to the commons tragedy of research libraries. When scholars, publishers, and librarians speak about the "value of scholarly information," they usually mean the perceived or expected use values to individuals of particular information products, rather than the exchange value of those products in the marketplace. But when these necessarily subjective, qualitative measures are used to justify the overall economic importance of scholarly information, value estimates (not restrained by market realities) become inflated.

When scholars are free to create new information without considering the economic market for that information, and, at the same time, are free to use published information at little or no cost, they are more likely to overestimate its value. Similarly, when publishers and librarians hear from the scholarly community only about the high actual or potential use value of this information and see continuing generous public financial support for its distribution and acquisition, their natural tendency is to distribute and acquire as much as possible. This surely demonstrates Taylor's last characteristic of scholarly information, its overproduction and overconsumption. The next question, then, is exactly how, in microeconomic terms, publishers, research libraries, and scholars interact with each other in the scholarly information marketplace.

\section{THE SCHOLARLY \\ INFORMATION MARKETPLACE}

The public good and uncertainty characteristics of scholarly information lead to distortions in the ideal competitive marketplace that economists use to predict supply, demand, and prices of goods and services. In a competitive market one would expect the total production and prices of relatively uniform scholarly journals to be balanced by the limited demand for individual journal titles. Instead, this marketplace is distorted by the dual and differential pricing strategies of scholarly publishers. Most publishers now charge one subscription rate to individuals and another substantially higher rate to libraries. And many European publishers charge substantially higher prices to U.S. libraries than to those in the rest of the world. Economists call these practices price discrimination, and define it more precisely as "selling the same product to different buyers at different prices, where the difference in price does not reflect cost differences in producing or selling the product. ${ }^{19}$

Price discrimination can only take place in noncompetitive markets (such as monopolies or competitive monopolies) where sellers can separate potential buyers into submarkets that respond differently to higher prices. Each submarket has a different "elasticity of demand" (or the product has different "price elasticities" in each submarket). Price elasticity is mathematically expressed as the percentage change in quantity demanded divided by the percentage change in the product price. It measures the responsiveness of buyers to changes in price. Highly elastic markets are those where higher prices quickly reduce demand or where lower prices quickly increase demand. Inelastic markets are those where price changes have little effect on demand. ${ }^{20}$

Current laws provide for the free transfer of copyright ownership from the scholars who write journal articles to the publishers who print, market, and distribute them. This effectively removes any marketplace incentives from the scholarly community. It also provides scholarly journal publishers with enough monopoly power that they can divide the market into separate submarkets with different price elasticities. Margaret Quinlin, an editor at Aspen Publishers, recently wrote a special report for the Society for Scholarly Publishing (SSP), in which she states clearly how important publishers feel price elasticity is in setting prices for their publications. "Price elasticity has a direct bearing on the pricing of publications," she says. "The publisher who lowers the price of . . . [a specialized publication with a 'price-inelastic demand schedule'] will 
not increase [sales] volume significantly. ... In short, total revenues will be reduced and circulation will not be increased. ${ }^{\prime 21}$

Individual demand for scholarly journals is more elastic than library demand. As early as 1977, Fritz Machlup pointed out the extent to which this is true. "Publishers . . . have given up the idea of selling to individual buyers [only],"' he said, "and are determined to charge what the traffic will bear in the supposed inelastic range of the demand curve-the research libraries., "22

In meetings with librarians, publishers argue that price increases to libraries result from overall increases in the fixed and variable costs of publishing ${ }_{,}^{23}$ the fluctuating value of the dollar abroad, which makes it necessary to compensate for expectations of a weakened dollar by setting higher prices in the U.S. market, ${ }^{24}$ and the many new and increasingly narrow scientific and scholarly specializations, which force fixed costs to be distributed over a narrower base. ${ }^{25}$ Publishers also argue that, although the marginal costs of producing journals for these different markets are about the same, the value or marginal benefit of the journal to each submarket is different enough to justify a higher price to research libraries. They reason that in libraries journals will be used by many readers, but the individual subscriber's copy will only benefit one, or, at most, a few.

The magnitude of recent price increases and the size of the price differentials, however, have convinced most research librarians that "publisher profit is the driving force behind the recent escalation of serial prices, ,'26 and that "'publishers of academic journals have sufficient monopoly power to engage in price discrimination. ${ }^{\prime 27}$ In a recent editorial, James Thompson singled out for particular criticism those "few publishers, owned and directed by large multinational holding companies," which openly seek monopoly power. He quotes Robert Maxwell, the owner of the Pergamon journals, who outlined his business strategy thus: "If Pergamon could win the trust of scientists it could establish the standard journal in each specialization, and that would give it a series of publishing monopolies . . . scientists are not generally as priceconscious as other professionals, mainly because they are not spending their own money. "28

At a fall 1988 seminar on the future of scholarly journals sponsored by the Society for Scholarly Publishing (SSP); librarians, publishers, and scholars exchanged views on the present and future economic viability of the journal system as it presently exists. Mr. Maxwell's assessment of the price-consciousness of scholar/scientists is corroborated in large part by the remarks of Robert Peet, a biologist who participated in the SSP seminar. "As a scholar," said Peet, "I am reasonably happy with the current status of scholarly journals." He did acknowledge the existence of both a "library problem" and a "publisher problem" caused by the increasing "store of human knowledge" and the exponential growth in the number of researchers worldwide and their resulting publications. But he argued for "one fundamental principle ... [to] constrain all solutions to these problems. That is, there must be free access for all scholars to journal articles. We will tolerate, grudgingly, travel as a necessity. But, we will not tolerate a strict pay-for-use system.',29 To the extent that this view is held by most scholars, any hope that a competitive, free-market, vendor/consumer relationship can be established between publishers and scholars is probably unrealistic.

In summary then, the scholarly information marketplace is characterized by producers (academic scholars) who turn over gratis, through copyright transfer, the ownership of their products (scholarly journal articles) to sellers (scholarly publishers), who in turn earn a profit, not by selling to the ultimate consumers (again academic scholars), but to publicly supported agencies (research libraries) acting on behalf of the entire scholarly community to organize, store, and provide free or low-cost access to these products. As Herb White puts it, "natural selection and the pressures of the marketplace simply do not apply here. ${ }^{\prime 30}$ 
The product exchanged in this marketplace, scholarly information, has many characteristics which make it quite different from free-market goods and services. Most notably, it easily "leaks," providing extra free or low-cost benefits to the scholarly community at large; and yet wide public distribution will in the long run discourage the primary mechanism now available for its distribution (scholarly publishing). Finally, the economic value of this product is distorted because its expected or perceived use value for individual consumers is confused with exchange value in the scholarly information marketplace. How has this economic situation become so dangerously distorted when it is in our collective best interest to keep it healthy? The principle underlying the "tragedy of the commons" may provide a key to the answer.

\section{THE TRAGEDY OF THE COMMONS}

The central story and dilemma of Garrett Hardin's 1968 essay in Science can be briefly summarized as follows. All the herdsmen of an agrarian community use a free open pasture or "commons" to graze their cattle. This arrangement works reasonably well for centuries because wars, disease, etc. keep the number of herdsmen and their cattle well below the capacity of the land. Finally, however, a day of reckoning comes when the pasture is full and the "inherent logic of the commons remorselessly generates tragedy."

Each economically "rational" herdsman seeks to get the most benefit possible from the commons and asks himself, "What value will I gain or lose by adding one more animal to my herd?" The positive value will equal all the proceeds from the eventual sale of the additional animal. The negative value will equal the overgrazing damage to the commons caused by one more cow. But, since this negative value is shared by all the herdsmen, the rational herdsman concludes that his share of this damage is much smaller than the profit one more cow will generate. The tragedy inevitably follows because each and every rational herdsman sharing the commons reaches the same conclusion.
The end of Hardin's little drama is worth quoting verbatim:

Therein is the tragedy. Each man is locked into a system that compels him to increase his herd without limit-in a world that is limited. Ruin is the destination toward which all men rush, each pursuing his own best interest in a society that believes in the freedom of the commons. Freedom in a commons brings ruin to all. ${ }^{31}$

Hardin goes on to point out that problems of pollution are examples of the tragedy of the commons in a reverse way. Instead of exploiting and thereby, depleting or taking something out of the commons, rational users decide to put in damaging things like sewage, toxic wastes, noise, or unpleasant advertising signs. ${ }^{32}$

\section{"Perhaps most sadly of all, we re- search librarians, who are charged with managing this commons, also encourage the exploitation and pollu- tion of the research library commons, and compound the tragedy, by insist- ing on comprehensive collections and unlimited free access for any and all potential users."}

Unfortunately, both the depletion and pollution manifestations of the tragedy of the commons can be applied to the current economic crisis in our system of scholarly communications. Publicly supported research libraries share many of the characteristics of the commons. Publishers, scholars, and even research librarians are all guilty of depleting and/or polluting this commons in the ways they "rationally" seek maximum benefit from its economic (budget) and scholarly information (books and journals) resources. The price discriminating publisher, like the herdsman who chooses to add more cows to his herd, exploits the research library commons by rationally deciding to maximize profits and charge whatever the traffic will bear in the inelastic range of the demand curve. The scholar who furthers his or her career or research goals by publishing as much as possible, and then insisting on 
free access to all other published information that might be of use, shares attributes with the independent, free-enterpriser who fouls his own nest with pollution. Perhaps most sadly of all, we research librarians, who are charged with managing this commons, also encourage the exploitation and pollution of the research library commons, and compound the tragedy, by insisting on comprehensive collections and unlimited free access for any and all potential users.

A deep-seated belief in the efficacy of the free-market system and Adam Smith's "invisible hand" (that is supposed to create greater prosperity for all if we each follow our own best interest) underlies the actions and views of each of these participants in the scholarly information marketplace, including research librarians. Katina Strauch, the head of Collection Development at the College of Charleston $\mathrm{Li}$ brary, in a recent talk on the economic relationships among librarians, vendors, and publishers, argued passionately and effectively for the need to preserve our competitive system where "the government does not dictate whom you must deal with or at what price. ${ }^{\prime 33}$ But when we face the problem of managing a commons, says Hardin, "we can make little progress

. until we explicitly exorcise the spirit of Adam Smith ... [ [who] contributed to a dominant tendency of thought that has ever since interfered with positive action based on rational analysis, namely, the tendency to assume that decisions reached individually will, in fact, be the best decisions for an entire society. ${ }^{\prime 34}$

Economists, on the other hand, realize that conditions of free choice for consumers and profit maximization by producers do not always result in socially desirable consequences. In 1977, economist Fritz Machlup pointed out the long-term consequences of making the scholarly publishing industry dependent on what he called the "grants economy," that is, the resources produced and paid for by recipients of public or private grants instead of private consumers paying out of their incomes. "Should trends of the recent past continue," Machlup said, "it would be impossible for the private sector of the [publishing] industry to survive if it had to rely on ... sales to private buyers not aided by grants. Whether the industry can be viable in the grants economy at the present rates of growth of costs on the one hand, and of grants on the other hand, is the question. ${ }^{135}$ In a 1979 review of the theoretical basics of economic analysis for Library Trends, Richard McKenzie included the following statement as a major element in his "economist's paradigm":

There is a tendency for individuals within very large groups to fail to pursue "common goals" even when the goals are agreed upon by all group members. Therefore, voluntary collective action is not likely in very large groups. [italics in the original] ${ }^{36}$

This is a very elegant synopsis of the crux of the tragedy of the commons. Unfortunately, McKenzie did not go on to explore the implications for library economics of this part of his paradigm.

Herb White has been one of the few librarians to state clearly some of these implications. For instance, here are his concluding remarks to a group of scholarly publishing executives: "unbridled growth in the number of publications, in their size, and in their price, with all of this dumped on one pliant customer community, cannot work in the future. Not necessarily because librarians will become more assertive ... but because there is no growth in the resources of what continues to be the one and only customer community. ${ }^{\prime \prime 37}$ In other words, voluntary collective assertiveness among research librarians is unlikely, even though we may all agree that collective assertiveness would help. Instead, White argues, only the exhaustion of our collective budget resources will bring an end to the spiraling growth in scholarly journal numbers and prices.

If this happens, the most important tragic consequence for our current system of scholarly communication will be the slow death of research libraries as much more than archives of the past. Their ability to collect and provide access to the current scholarly record will be gradually destroyed. The publishers and scholars who depend on the research library's budget and scholarly information resources will be forced to find alternative, and probably 
more expensive, ways to disseminate and gain access to these resources. In the face of such discouraging predictions and the inexorable and seemingly inevitable forces leading to a research library commons tragedy, what can be done to insure that research libraries (or some reasonable alternative) will continue to carry out the mission of collecting, preserving, and providing access to the scholarly record? The concluding section of this essay will explore a few tentative possibilities for preventing this tragedy and managing the research library commons for the long-term future.

\section{MANAGING THE RESEARCH LIBRARY COMMONS}

Over the past ten years or so, probably the most frequently suggested strategy for research libraries to deal with the spiraling quantities and costs of scholarly information has been to use new electronic and optical information storage and retrieval systems tied together in regional, national, and international networks. The combination of these new information storage and sharing technologies, proponets argue, should make possible effective storage and retrieval of much larger quantities of information at much lower unit costs. In addition, networks would permit direct access to remote resources, reducing the necessity for every research library to collect comprehensively.

A very influential statement of this vision of a technological future for research libraries was the 1982 Matheson-Cooper Report sponsored by the Association of American Medical Colleges and the National Library of Medicine. The report called for strategic planning initiatives and major investments in information technology to manage information resources within integrated networks. ${ }^{38}$ However, an important characteristic of the class of human problems represented by the tragedy of the commons, says Hardin, is that they are not particularly amenable to technical solutions. "A technical solution," he says, "may be defined as one that requires a change only in the techniques of the natural sciences, demanding little or nothing in the way of change in human values or ideas of morality. ${ }^{39}$ To the degree that technology simply changes the dimensions or capacity of the research library commons to deal with larger volumes of information, or transforms that information into formats with lower unit costs, we may be only delaying the inevitable tragedy (or perhaps compounding it because of the high cost of the new technologies!). This is because the basic human patterns of overproduction and overconsumption of scholarly information described above will remain unchanged.

Matheson and others have argued, however, that this report's recommendations are not, in their essence, a set of proposed technological solutions, but rather an "attempt to define the basis for a different library paradigm for the future. ${ }^{\prime 40}$ She quotes Thomas Kuhn ${ }^{41}$ who remarked that the process of knowledge transformation may really mean the "reconstruction of group commitments among the community of scientists." Such a reconstruction, Matheson says, "with respect to the management of information in the health sciences would be an exceedingly useful thing. ${ }^{\prime 42}$ Virginia Holtz takes this Kuhnian analogy of the paradigm shift further by suggesting that the Matheson-Cooper Report provides a focus for a new world view where the "information user, rather than the library, and information per se, rather than the instruments which carry it, have become the central concerns of our discipline. ${ }^{\prime 43}$ In essence, what Matheson and others of this school are proposing is "the deinstitutionalization of [research] libraries" so they will shift away from building definitive collections of books, journals, and bibliographic data and, instead, "conceive of different ways to enhance the utility of our major [scholarly information] assets, to improve the productivity of the academic community. ${ }^{\prime 44}$

Short of the kind of major rethinking of the mission of research libraries Matheson proposes, other useful suggestions have been made to manage research libraries in ways to avoid their over-exploitation by information entrepreneurs. Stephen Feinman argues that some sort of government regulation of the scientific and technical 
information industry may be needed, and that this may best be justified if we cease to focus on the public goods aspects of information and think instead of "knowledgeinformation-communication packages" as a form of capital. Feinman envisions "an information industry structured much like the banking industry":

Information banks would be chartered at both the national and state levels ... The producers of knowledge, which would be captured by these banks, might be treated in the same manner as individuals with time deposits. . . The users of the system . . . might well be treated as people or institutions that obtain a loan [to be] paid back in terms of principal and interest.

Access to the banks would be broadly regulated by the central bank but controlled by the individual institutions. . . . The central bank, controlled by the government, would also define the limits of research, since knowledge that is not captured cannot be communicated. ${ }^{45}$

As Feinman notes, this scenario would have dramatic implications for all parts of the scholarly communications process, including elimination of the need for or purpose of copyright. Since copyright is one of the keystones supporting the commercial exploitation of scholarly information resources and products, most proposals to manage these resources better involve changes in copyright laws. Professor Peet, at the SSP seminar, proposed changes in these laws that would reduce "copyright on journal articles ... to a short period of time, perhaps one or two years." This would preserve incentives for publishers to provide the immediate access "critical to the active researcher, [but] allow libraries to acquire backruns of . . . journals at little or no cost." ${ }^{\prime 46}$

A growing number of research librarians now argue that ways should be found to reduce the role of commercial publishers in the scholarly communication process dramatically. For instance, Pat Battin argues that the library should become the center of a new kind of restructured university that controls and manages the whole process of creating and disseminating ideas to advance knowledge for the public good. ${ }^{47}$ Similarly, Richard Dougherty and Brenda Johnson suggest that "if scholars and librarians can't communicate easily through publishers, we must learn to communicate around them. ${ }^{\prime 48}$ And James Thompson thinks that "the idea of the academy retaking control of the bulk of scholarly publishing is being forced into consideration by the practices of commercial publishers. ${ }^{\prime 49}$ But even if these librarians are all correct, and "there is no technical or economic reason" why commercial publishers must remain a part of the "information conduit" for scholarly communication, ${ }^{50}$ formidable barriers remain to changing the centuriesold incentives and economic structures of our current scholarly information marketplace. Individual publishers and scholars, like the individual herdsmen in Garrett Hardin's story, are convinced that their journals and articles are all outstanding and should easily get a share of the limited budget resources of research libraries. "Each of them thinks," as Herb White puts it, "that while indeed other and more marginal publishers [and scholars] might suffer, they would be unaffected. ${ }^{\prime \prime 51}$

Each of the solutions proposed above, as with other "commons" problems faced by our society, would involve a radical restructuring of the ways scholars, publishers, and librarians think about and use research library resources. Appeals to individual publishers, scholars, or even librarians to restrain themselves for the common good will not work. As Hardin puts it, appeals to conscience "set up a selective system that works towards the elimination of conscience from the race ... [ [since] to conjure up a conscience in others is tempting to anyone who wishes to extend his control beyond the legal limits." What we need instead, says Hardin, is "mutual coercion mutually agreed upon, ${ }^{\prime \prime 2}$ that is, we must eventually give up altogether the idea of a commons open to unrestrained exploitation. In place of individual freedom to exploit, we must learn what Kenneth Boulding (1977) calls simply a sense of "community." But this is a "long and painful learning process. ",53

If we are going to bring about the changes needed to avoid the gradual destruction of our research library commons, it will take leadership and a common understanding of the grave 
implications of continuing on our present course. It seems clear that current market incentives are much too strong to expect the initial leadership or understanding to come from publishers or research scholars. Because research libraries have been charged by society to manage our nation's scholarly information resources, research librarians must assume this leadership role and develop strategies to avoid the approaching tragedy. The first step, I would argue, is to educate ourselves and our publisher and academic scholar colleagues about the true economic implications of the current scholarly information marketplace.

It is encouraging to note that profes- sional library associations such as the Association of Research Libraries have recently taken major steps to begin this process of education. Witness the two 1989 studies published as part of ARL's Project on Serial Prices. ${ }^{54}$ These studies present their recommendations backed with convincing empirical evidence and solid economic analysis. They also emphasize the importance of an "ongoing program of education and publicity." 55 Only when the impending commons tragedy of our nation's research libraries is widely understood will we be able to build the necessary political consensus for change.

\section{REFERENCES}

1. Peter R. Young and Kathryn Hammell Carpenter, "Price Index for 1989: U.S. Periodicals," Library Journal 114(7):43-49 (Apr. 15, 1989), p.47.

2. Herbert S. White, "The Journal That Ate the Library," Library Journal 113(9):62-63 (May 15, 1988), p.63.

3. Ibid., p.62.

4. Ibid.

5. Garrett Hardin, "The Tragedy of the Commons," Science 162:1243-48 (Dec. 13, 1968) reprinted in Managing the Commons, ed. by Garrett Hardin and John Baden (San Francisco, Calif.: W.H. Freeman and Company, 1977), p.16-30.

6. Harlan Cleveland, The Knowledge Executive (New York: E.P. Dutton, 1985), p.29-35.

7. Ibid., p.73.

8. Pat Molholt, "On Converging Paths: The Computer Center and the Library," Journal of Academic Librarianship 11:284-88 (Nov. 1985), p.284.

9. Robert S. Taylor, Value Added Processes in Information Systems (Norwood, N.J.: Ablex, 1986), p.20-21.

10. Fritz Machlup, Knowledge: Its Creation, Distribution, and Economic Significance, Vol. III, The Economics of Information and Human Capital (Princeton, N.J.: Princeton Univ. Pr., 1984), p.159-60.

11. Lawrence White, "The Sensible Economist's Guide to the Economics of Information," in The Economics of Information, ed. by Jana Varlejs (Jefferson, N.C.: McFarland \& Co., 1982), p.20.

12. Fritz Machlup, Knowledge: Its Creation, Distribution, and Economic Significance, Vol. I, Knowledge and Knowledge Production (Princeton, N.J.: Princeton Univ. Pr., 1980), p.208.

13. Sanford V. Berg, "Structure, Behavior, and Performance in the Scientific Journal Market" (Yale University, unpublished doctoral dissertation, 1970), p.6.

14. Machlup, Knowledge and Knowledge Production, p.207-208.

15. Aatto J. Repo, "The Value of Information: Approaches in Economics, Accounting, and Management Science," Journal of the American Society for Information Science 40:68-85 (Mar. 1989), p.81-82.

16. Ibid., p.81.

17. Berg, "Structure, Behavior, and Performance." See also Sanford V. Berg, "An Economic Analysis of the Demand for Scientific Journals," Journal of the American Society for Information Science 23:23-29 (January-February 1972).

18. Machlup, Knowledge and Knowledge Production, p.220-22.

19. Patrick Joyce and Thomas E. Merz, "Price Discrimination in Academic Journals, " Library Quarterly 55(3):273-83 (1985), p. 274.

20. David N. Hyman, Modern Microeconomics: Analysis and Applications (St. Louis: Times Mirror/ Mosby, 1986), p.33-35.

21. Margaret M. Quinlin, "Pricing: Its Place in the Marketing Mix \& Its Contribution to Profit," Society 
for Scholarly Publishing Special Report Series 3:1-12 (1988), p.2-3.

22. Fritz Machlup, "Publishing Scholarly Books and Journals: Is It Economically Viable?" Journal of Political Economy 85:217-25 (1977), p.221.

23. Brian Cox, "Scholarly Journal Prices," The Serials Librarian 13:135-38 (Oct./Nov. 1987).

24. Charles Hamaker, "Serials Costs and the Carrying Ability of Serials Budgets 1987," The Serials Librarian 13:129-34 (Oct./Nov. 1987).

25. Richard M. Dougherty and Brenda L. Johnson, "Periodical Price Escalation: A Library Response," Library Journal 113(9):27-29 (May 15, 1988).

26. Ibid., p. 28.

27. Joyce and Merz, "Price Discrimination," p.224.

28. James C. Thompson, "Journal Costs: Perception and Reality in the Dialogue," College \& Research Libraries 49:481-82 (Nov. 1988), p.481.

29. Robert K. Peet, "'Response to Ms. Karen Hunter, 'The Future of the Journal: A Publisher's Perspective," " Unpublished manuscript of remarks presented at the Seminar on the Future of the Scholarly Journal (Chapel Hill, N.C.: Society for Scholarly Publishing, 1988), p.1-4.

30. Herbert S. White, "Scholarly Publishers and Libraries: A Strained Marriage," Scholarly Publishing 125-29 (April, 1988), p.127.

31. Hardin, "The Tragedy of the Commons," p.20.

32. Ibid., p.21-22.

33. Katina Strauch, "Response: The Image Maker Meets the Competition," The Serials Librarian 13:85-90 (Oct./Nov. 1988), p.87.

34. Hardin, "The Tragedy of the Commons," p.19.

35. Machlup, "Publishing Scholarly Books and Journals," p.221-22.

36. Richard B. McKenzie, "The Economist's Paradigm," Library Trends 28:7-24 (Summer 1979), p.15.

37. White, "Scholarly Publishers and Libraries," p.129.

38. Nina W. Matheson and John A.D. Cooper, "Academic Information in the Academic Health Sciences Center: Roles for the Library in Information Management," Journal of Medical Education 57(10, pt 2):1-93 (Oct. 1982).

39. Hardin, "The Tragedy of the Commons," p.16-17.

40. Nina W. Matheson, "The Author Replies: Neither True Nor False, but More or Less Useful," Bulletin of the Medical Library Association 72:32-34 (Jan. 1984), p.33.

41. Thomas S. Kuhn, The Structure of Scientific Revolutions, 2nd ed., enlarged (Chicago: Univ. of Chicago Pr., 1970).

42. Matheson, "The Author Replies," p.34.

43. Virginia H. Holtz, "Measures of Excellence: The Search for the Gold Standard," Bulletin of the Medical Library Association 74:305-14 (Oct. 1986), p.312.

44. Nina W. Matheson, "The Academic Library Nexus," College \& Research Libraries 45:207-13 (May 1984), p.207, 212.

45. Stephen Feinman, "Regulation of the STI Industry: A Historical Basis and Some Possibilities, " in Information Services: Economics, Management, and Technology, ed. by Robert M. Mason and John E. Creps, Jr. (Boulder, Colo.: Westview Press, 1981), p.60.

46. Peet, "'Response to Ms. Karen Hunter," p.7-8.

47. Patricia Battin, "The Library: Center of the Restructured University," College \& Research Libraries 45:170-76 (May 1984).

48. Dougherty and Johnson, "Periodical Price Escalation," p.28.

49. Thompson, "Journal Costs," p.482.

50. Ibid.

51. White, "The Journal That Ate the Library," p.63.

52. Hardin, "The Tragedy of the Commons," p.26.

53. Kenneth E. Boulding, "Commons and Community: The Idea of a Public," in Managing the Commons, ed. by Garrett Hardin and John Baden (San Francisco, Calif.: W.H. Freeman and Company, 1977), p.287.

54. Economic Consulting Services, Inc. "A Study of Trends in Average Prices and Costs of Certain Serials Over Time" (Washington, D.C.: 1989) and Ann Okerson, "Of Making Books There is No End: Report of Serials Prices for the Association of Research Libraries" (Eastchester, N.Y.: 1989).

55. Association of Research Libraries, "Association of Research Libraries' Project on Serial Prices: Overview and Summary" (Washington, D.C.: 1989). 